\title{
Life in the suburbs: artificial heat source selection for nocturnal thermoregulation in a diurnally active tropical lizard
}

\author{
NioKing Amadi ${ }^{1}$, Robert Belema ${ }^{1}$, Harrison Obodo Chukwu ${ }^{1}$, Daniele Dendi ${ }^{1,2,3}$, Amuzie Chidinma ${ }^{1}$, \\ Roger Meek ${ }^{4}$, and Luca Luiselli ${ }^{1,2,3}$ \\ ${ }^{1}$ Department of Animal and Environmental Biology, Rivers State University, Nkpolu-Oroworukwo, \\ P.O. Box 5080, Port Harcourt, Nigeria \\ ${ }^{2}$ Institute for Development, Ecology, Conservation and Cooperation, via G. Tomasi di Lampedusa 33, \\ 00144 Rome, Italy \\ ${ }^{3}$ Department of Zoology, University of Lomé, Lomé, Togo \\ ${ }^{4}$ British Herpetological Society, Regents Park, London, UK
}

Correspondence: Roger Meek (rogermeek85@aol.com)

Received: 19 June 2020 - Revised: 29 September 2020 - Accepted: 21 October 2020 - Published: 4 December 2020

\begin{abstract}
The rapid expansion of urban environments invariably presents a novel series of pressures on wildlife due to changes in external environmental factors. In reptiles, any such changes in temperature are critical since thermoregulation is the key driver in the function of many physiological processes. How reptiles adapt to such changes may vary from those species that are impacted negatively to others that have the behavioural flexibility to exploit new conditions. In this paper we describe retreat site selection, movements and aspects of the thermal ecology of the African lizard Agama agama in urban environments of West Africa. In early evening lizards began movement from late-afternoon core activity areas and ascended the walls of houses for overnight retreats. A high proportion retreated to locations in groups under or on top of warm electrical panels. The thermal potential these panels offered was the attainment of body temperatures equal to or higher than the minimum preferred body temperature ( $\mathrm{PBT} \approx 36^{\circ} \mathrm{C}$ in $\mathrm{A}$. agama) and hence increased physiological performance. The lizards that took advantage of the heat sources travelled further each day to and from diurnal activity areas than individuals that spent the night high on walls but not next to heat panels. There were both potential costs (enhanced predation pressures) and benefits (impacts on thermal ecology, retreat site selection) of this behaviour for lizards living in urban environments.
\end{abstract}

Retreat site selection is a key aspect in the study of adaptation, sociality and predation risk in vertebrates (e.g. Campbell and Tobler, 1984; Rasoloharijaona et al., 2003; Rial et al., 2010). The benefits from the thermal qualities of retreat sites are an important aspect for reptiles since body temperature levels influence, among others, rate of digestion, sprint locomotion, predation success and anti-predator tactics (Huey, 1982; Downes and Shine, 1998; Kearney, 2002; Morris and Lattanzio, 2020). Additionally, the effect of temperature on embryo fitness and offspring survival may be depen- dent on female reptiles selecting optimum location for egg deposition in a thermal context (Löwenborg et al., 2011) or in achieving optimum temperatures by diurnal basking (Lourdais et al., 2004). However, the benefits involve risks. For example, gravid female aspic vipers (Vipera aspis) bask in exposed locations to enhance embryo development through achieving optimum body temperatures but risk predation by predators such as raptors (e.g. Lourdais et al., 2004), and gravid female grass snakes (Natrix natrix) travel to communal egg-laying sites that provide optimum temperatures for embryonic fitness (e.g. Meek, 2017) but risk predation as a consequence of increased movement and exposure (e.g. Bon- 
net et al., 1999; Meek, 2017). Therefore, costs and benefits of thermal ecology are a critical aspect of reptile life history.

Selection of overnight retreats controls the microclimates that lizards experience when they are inactive, thus enabling them to thermoregulate by subtle movements within retreat areas (e.g. Porter et al. 1973; Hitchcock and McBrayer, 2006). Indeed, Porter et al. (1973) showed that a hypothetical reptile might more easily control body temperatures in overnight retreats than during periods of diurnal activity and may even be capable of maintaining preferred temperatures for longer.

Although retreat site selection in reptiles has been studied previously (e.g. Clark and Gillingham, 1990; Poche et al., 2005; Singhal and Johnson, 2007; Meek, 2008; CabreraGuzmán and Reynoso, 2010), data on overnight retreat selection and diurnal movement in relation to retreat site availability, especially in rapidly changing anthropogenic environments, are limited. Given that lizards possess limited dispersal capacities, they are particularly vulnerable to habitat changes. Ecological research efforts are traditionally devoted to natural and semi-natural habitats, but studies on reptiles living in anthropogenic environments can provide insight into the degree of adaptability that has enabled some species, for example A. agama, to be a widespread ecological success, both in terms of population densities and geographical distribution. Additionally, optimal escape theory suggests that the risks and benefits gained from the distances involved in travelling to retreat sites will impact on retreat site selection (Schlesinger and Shine, 1994; Webb et al., 2004; Meek, 2008), and how reptiles respond to anthropogenic environments is important from a conservation perspective.

Agama lizards (family: Agamidae) are a diverse group of tropical reptiles characterized by a great ecological plasticity (e.g. Harris, 1964; Cloudsley-Thompson, 1981) that has enabled some species to survive even in areas outside their native African range (Enge et al., 2004; Leache et al., 2009; Wagner et al., 2009). An example of this ecological plasticity is the rainbow lizard (Agama agama), an agamid that has adapted to life in suburban habitats throughout West Africa (Chapman and Chapman, 1964; Akani et al., 1999, 2011; Leaché et al., 2017) and has been the focus of numerous studies across African regions (e.g. Yeboah, 1982; Anibaldi et al., 1998; Adeoye and Ogunbanwo, 2007) including the Niger Delta of Nigeria (e.g. Akani et al., 2011, 2013). A diurnal species (Cloudsley-Thompson, 1981; Yeboah, 1982; Anibaldi et al., 1998), A. agama on occasion may also be active nocturnally (Pauwels et al., 2004). In the present paper, we investigate the links between retreat site selection and movement ecology of A. agama in urban areas of Rivers State, southern Nigeria. We address the following key questions:

1. Does A. agama retreat to low-level or elevated perches at night? This question is relevant because agamid lizards have been observed to shift from terrestrial to arboreal habits by night (Cloudsley-Thompson, 1981).
2. Does A. agama select vertical or horizontal substrata as retreats sites? This question is relevant because lizards often show species-specific preferences for vertical or horizontal perches, as they can maximize their sprint performances in the event of attempted predation (Cooper, 2006).

3. In retreat sites are A. agama solitary or do they cluster in groups? This question is relevant because A. agama has numerous predators (e.g. Luiselli et al., 2002) and when in inappropriate retreat sites may be at much higher risk of predation. Selection of appropriate retreat sites may minimize predation risk by employing group behaviour at night (Yorzinski and Platt, 2012; Ellison et al., 2019).

4. Is there any thermal/anti-predation benefit in the association with heat panels as retreat sites? This question is relevant because thermal sensitivity in lizards impacts on their ability to feed and evade predators due to increased muscular energy and running speeds with increasing body temperatures.

5. Do the lizards exhibit sexual and age differences in movement patterns between retreat sites and feeding areas? This question is relevant because we need to understand whether the benefits of increased heat availability are sex- or age-specific, two aspects that are relatively poorly known in tropical lizards studied at present. In the context of question 5, we also report some observations on the predation events suffered by A. agama at the study areas.

\section{Materials and methods}

\subsection{Study area}

The field work was carried out in the Rivers State, in the eastern Niger Delta region of southern Nigeria. The area has a wet tropical climate, with a temperature average of $25-28^{\circ} \mathrm{C}$ (up to $32-34{ }^{\circ} \mathrm{C}$ by day) throughout the year. The wet season occurs from April to September and the dry season from October to March (Amadi, 2017). The area is characterized by a forest-plantation mosaic, with numerous small villages and a few large urban centres, with Port Harcourt the largest city in the state (Amadi, 2017).

\subsection{Protocol}

The field study was carried out from 12 January to 22 February 2020, around 81 houses and surrounding gardens, in 61 communities of Rivers State. Field surveys were made every day during this time period. The geographic coordinates of the various sites are given in Appendix A.

Data were gathered daily between 17:00 and 24:00 (Lagos standard time) during which time the whole garden/private property of each sampled house was systematically searched 
with the aid of flashlights from mobile devices to detect the presence of lizards in their overnight retreats. The lizards in each microhabitat type were carefully counted and photographed without disturbance. The following microhabitat/substratum types were classified: trees and bushes, cement basements, and walls. When lizards were observed on cement basements and walls, we recorded whether they were sleeping/resting within nearby electrical changeovers or switches (i.e. electric panels), which were normally located at the front or back of houses. We recorded whether the various individuals were sleeping/resting (i) on a vertical or horizontal substratum, (ii) alone or in a group and (iii) the number of individuals forming each group was also noted. We defined "in a group" lizards that had at least another conspecific individual at less than $30 \mathrm{~cm}$ linear distance. The temperature $\left({ }^{\circ} \mathrm{C}\right)$ of the substratum used by lizards for resting was recorded by Benetech Lasergrip GM320 laser electronic thermometer $\left(0.1^{\circ} \mathrm{C}\right.$ resolution and accuracy of $\left.\pm 0.2^{\circ} \mathrm{C}\right)$. The height of the lizards from the ground (in $\mathrm{cm}$ ) was measured with a tape. Furthermore, we recorded the presence of predators (cats and snakes) within each of the surveyed private properties and catalogued all instances of direct predation on A. agama. Between 17:00-18:00, we also conducted systematic observations of several individuals in order to measure exactly the linear distances (in $\mathrm{m}$ ) they moved from their "late-afternoon core activity" area to overnight retreat sites. Eighty-four lizards were monitored: 20 juveniles, 31 males and 33 females by focal observations. Each individual was followed for at least $30 \mathrm{~min}$ from a distance of about $10 \mathrm{~m}$, in such a way to avoid direct disturbance by the observer on its movements. Then, after each individual was observed in an overnight retreat the distance was measured with a tape from the "core" area (i.e. a point situated roughly in the middle of the area where the lizard was seen while active) and the overnight resting location. Given that we did not monitor any individual for more than one day, we could not determine whether distance travelled by lizards could be influenced by factors such as climate and/or social interaction on a daily basis.

Data from individuals were collected once at each house and not repeated within the structure, thus avoiding pseudoreplication. Frequency of predation events by snakes was recorded by inducing regurgitation of ingested meals by snakes that were encountered in the studied suburban areas (see Luiselli and Amori, 2016); predation by cats was observed directly.

In this paper we discuss some of the possible benefits of attaining preferred body temperatures when in retreat sites by invoking $Q_{10}$ effects on physiology. $Q_{10}$ is a measure of thermal sensitivity of physiological processes with increases of $10^{\circ} \mathrm{C}$. This enables lizards and other ectotherms to (for example) run faster or increase digestion rates. Most of the $Q_{10}$ effects on physiological processes in reptiles range between
2 and 3 and are determined from

$$
Q_{10}=(R 2 / R 1)^{10 C /(t 2 / t 1)},
$$

where $Q_{10}$ the measure of rate change is a unitless quantity and derived from $R$ the rates of change between temperatures $t 2$ and $t 1$ in C. A $Q_{10}$ of 1 would indicate thermal independence; values greater than 1 indicated the physiological processes have increasing thermal dependence. An example of $Q_{10}$ effects is increased muscle power and subsequent increases in reptile running speeds with increasing body temperature (Bennett, 1990). This in turn impacts on the ability of a reptile to secure prey or escape predators.

\subsection{Statistical analyses}

Frequency differences of lizards in retreats were evaluated by a three-way contingency table $\chi^{2}$ to test the independence of substratum type, group or alone, and vertical versus horizontal substratum. Correlation between height of the wall and number of sleeping lizards was assessed by Pearson's product moment correlation coefficient. Differences in the substratum temperature of lizard sleeping spots between electric panels versus other substratum types were evaluated by two-way ANOVA, with type of substratum and daytime (Lagos standard time) as the factors. For distances moved versus association or non-association with electric components data sets were first examined for normality using Anderson $a^{2}$ tests. These showed normal distributions in both sexes ( $a^{2}$ from 0.21 to $0.32, P$ values from 0.49 to 0.77 ), and hence comparisons were made using ANOVA. Temperatures of electric boxes, where lizards were found, were compared with temperatures of retreat sites without artificial heating using simple percentages. These results were then evaluated against known minimum preferred body temperatures (PBTs) in A. agama (James and Porter, 1979) using two-tailed probability $z$ scores of the differences in percentages. A sample precision test, which evaluates sample size, indicated maximum error was $\pm 8.9 \%$ at the $95 \%$ interval. We used one-way ANCOVA for testing the heterogeneity of the slopes of the regression line of the general correlation of wall height $(\mathrm{cm})$ against the number of sleeping lizards between electric panels and other retreat sites. Comparison of means was by the Mann-Whitney $U$ test and comparison of variances by Levene's test. Both tests are less sensitive to departures from normality. The null hypothesis for Levene's test is $H_{0}: \sigma_{1}^{2} / \sigma_{2}^{2}=1$ at $\alpha=0.05$. In the text, means are followed by \pm 1 standard deviation. All statistical analyses were performed with SigmaPlot 14.0 software and Minitab V17, with $\alpha$ at 0.05 .

\section{Results}

A total of 166 electric panels were surveyed, and 43 of them (34.8\%) were occupied by at least one A. agama lizard. 
(a)

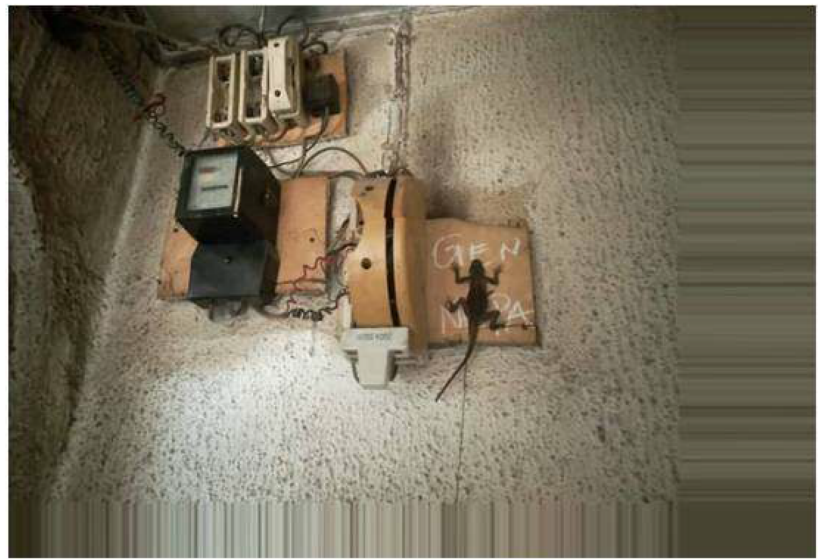

(b)

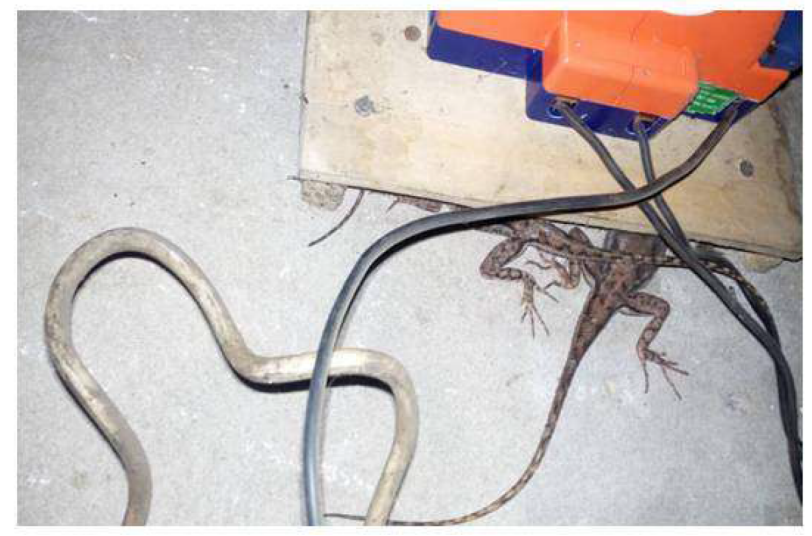

Figure 1. Example of Agama agama resting on (a) or below (b) warm electric panels for overnight retreats.

Overall, 435 lizards were observed in overnight retreats: $96 \%$ were observed on cement walls, at an average height of $101.8 \pm 86.8 \mathrm{~cm}$ (median $=78 \mathrm{~cm})$. Only $4 \%$ of the observed individuals were on a tree/bush within the properties (frequency differences in the use of retreat site location were significantly different, $\chi^{2}$ test, $\left.P<0.0001\right)$. On multiple occasions $(n=14)$, we observed that from around 18:00, lizards started heading towards retreat sites from nearby bushes, fences, and ascended walls and positioned themselves under or on top of warm electrical panels. The panels regulate electrical energy sourced from personal generators or power from national grid and emitted heat. Lizards $(n=144$, $33.1 \%$ ) were observed within $5 \mathrm{~cm}$ distance (Fig. 1a), under or on top of these electric panels (Fig. 1b). Most were clustered in groups (Fig. 2): only $1.4 \%$ of the total observed $(n=435)$ were solitary during nocturnal inactivity $\left(\chi^{2}\right.$ test, $P<0.0001)$. When lizards were found in groups, numbers ranged from 2 to 12 and averaged $3.6 \pm 2.8$ individuals (media $n=3$ individuals). Moreover, $92.6 \%$ of the observed in-

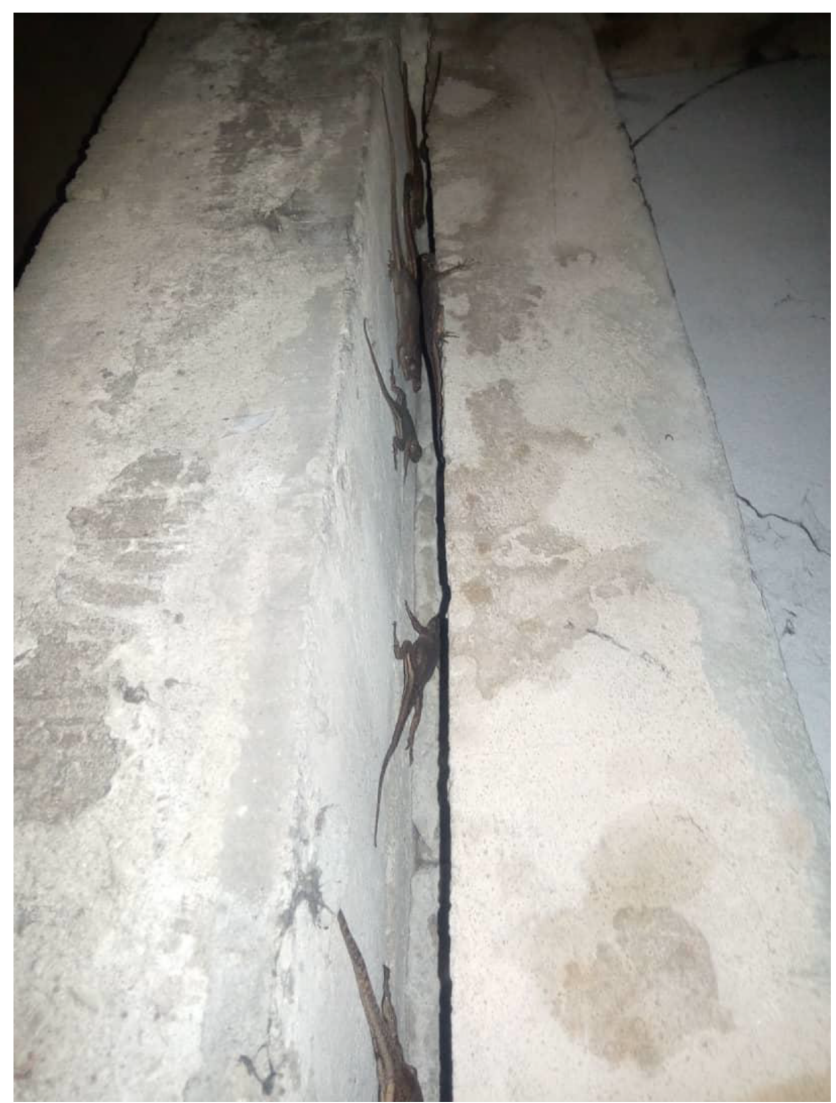

Figure 2. Example of overnight clustering on walls in Agama agama from the study locality.

dividuals were found on vertical substrata and only $7.4 \%$ on horizontal substratum $\left(\chi^{2}\right.$ test, $\left.P<0.0001\right)$. The numbers of lizards were not correlated to the height of the wall when they used electric panels $(P>0.05)$, whereas it was significantly positively correlated when they selected other retreat sites $(r=0.765, P<0.001)$. A heterogeneity of slopes test revealed that the two regressions did not differ significantly (one-way ANCOVA; $P>0.05$; Fig. 3). Lizards that were located next to electrical panels (mean $=135.5 \pm 64.3 \mathrm{~cm}$ ) were found at significantly higher elevations than those that were not next to panels (mean $=98.9 \pm 82.4 \mathrm{~cm}$, the MannWhitney $U$ test, $w=1418, P=0.0009$ ) with the variances of heights around the means in good agreement (Levene's $W=0.001, P=0.98$ ).

Mean substratum temperature was significantly higher at electric panel retreat sites than non-artificially heated areas $(F=2.22, P=0.007$; Fig. 4$)$ and also when diurnal temperatures were included in the analysis (two-way ANOVA: $F=1.763, P=0.023)$. So they were different in both structure (panels versus no panels) and temperatures (heated areas versus non-heated areas). The frequency distributions of lizard heights on walls next to heat panels and heights of lizards not located on unheated wall areas are given in Fig. 5. Diurnal temperatures were in good agreement for all the dif- 


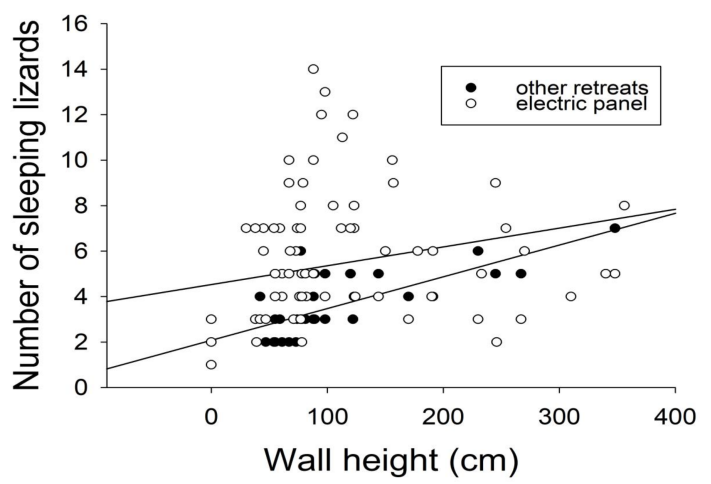

Figure 3. Relationship between wall height and number of sleeping rainbow lizards (Agama agama) in Port Harcourt city (southern Nigeria). The two regression lines respectively show lizards using electric panels as retreat sites and lizards using other retreat sites. For the statistical details, see the text.

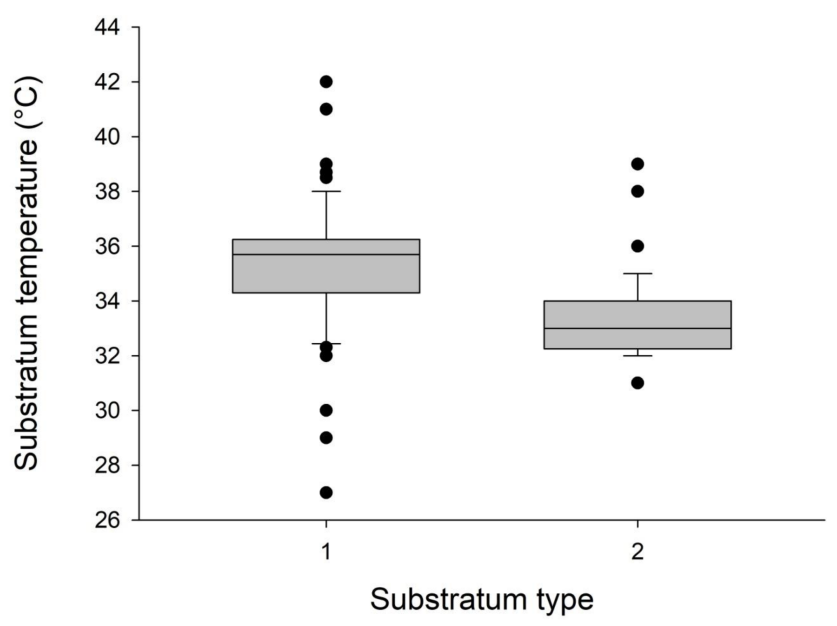

Figure 4. Box plots showing differences between substratum temperature $\left({ }^{\circ} \mathrm{C}\right)$ at electric panels (symbol 1 on the $x$ axis) and at nonartificially heated locations used by lizards (symbol 2 on the $x$ axis). Mean, range, standard deviation and outliers are shown.

ferent substratum types $(F=0.69, P=0.913)$. Percentage comparisons of temperatures at electric boxes versus temperatures at non-artificially heat areas indicated that $59.3 \%$ of lizards close to the electric boxes could potentially achieve nocturnal PBTs equal to or higher than the known minimum PBT in A agama $\left(\approx 36^{\circ} \mathrm{C}\right)$ compared to $7.5 \%$ that were at non-artificially heated localities $(z=7.48, P<0.001)$. The temperatures for both areas in relation to minimum PBT are shown in Fig. 6.

A greater number of adults (males $74 \%$, females $57.6 \%$ ) spent the night close to the electrical panels than juveniles $(25 \%, n=25$; juveniles versus males, $z=3.8, P<$ $0.0001 n=31$, juveniles versus females $z=2.45, P=$ $0.014, n=33$ ). However, there were no significant differences between males and females $(z=1.4, P=0.17$ all two-tailed tests). Males $(n=31$, mean $=15.6 \pm 101 \mathrm{~m})$ travelled greater distances between "late-afternoon core diurnal activity areas" than females $(n=33$, mean $=10.1 \pm 6.7 \mathrm{~m})$, and both sexes travelled further than juveniles $(n=20$, mean $\left.=5.2 \pm 41 \mathrm{~m} ; F_{(2,81)}=9.95, P<0.0001\right)$, with Tukey post hoc tests indicating that the differences between each category were significantly different in all groups. Lizards that retreated next to or under electric panels travelled further each day to "late-afternoon core activity areas" than individuals that did not spend the night next to electrical panels (males $=21 \pm 15.2$ versus $13.7 \pm 8.74 \mathrm{~m}$; females $=14.8 \pm 7.7$ versus $8.5 \pm 4.1$ ), but the difference was only significant in females (males, $F_{(1,29)}=2.76, P=0.11$; females, $\left.F_{(1,31)}=9.06, P=0.005\right)$.

Recorded predation events upon A. agama at the study areas (total $n=66)$ included domestic cats $(n=21)$ and the snakes Lamprophis fuliginosus $(n=32)$, Lamprophis lineatus $(n=7)$, Crotaphopeltis hotamboeia $(n=5)$, and Naja melanoleuca $(n=1)$.

\section{Discussion}

Our study has presented several new findings on the biology of A. agama in the suburban areas of Port Harcourt: (i) most lizards used vertical surfaces for overnight retreats; (ii) most spent the night in groups rather than as solitary individuals; (iii) the lizards used locations on relatively high cement based walls for overnight retreats; (iv) adults preferentially spent the night next to or on electric panels, but this was less evident in juveniles; and (v) there were significant differences between males, females and juveniles in the distances travelled between late-afternoon core activity areas and overnight retreats. In addition, cats and snakes were found to be the main observed predators for A. agama living in suburban environments. However, it is implicit in this study that we did not measure lizard body temperatures since we were careful to avoid disturbing behaviour, which may impact on subsequent behaviour. Nevertheless we are confident that lizards resting on or next to heat panels gained extra heat compared to those lizards that did not and were better capable of achieving or exceeding minimum preferred body temperatures.

There are three possible advantages that elevated retreat sites can confer: (1) reduced risk of predation from terrestrial predators, (2) shelter from rain (Port Harcourt has an extremely wet climate, especially from April to September), and (3) passive basking close to warm electric panels potentially enables lizards to achieve body temperatures within the minimum PBT threshold. Overnight clustering in groups by $A$. agama contrasts with territorial behaviour in diurnal habitats (e.g. Yeboah, 1982; Madsen and Loman, 1987; Anibaldi et al., 1998) and might suggest that group behaviour is an anti-predatory strategy (Landeau and Terborgh, 1986; Krause et al., 2002; Beauchamp, 2013) or that electrical pan- 


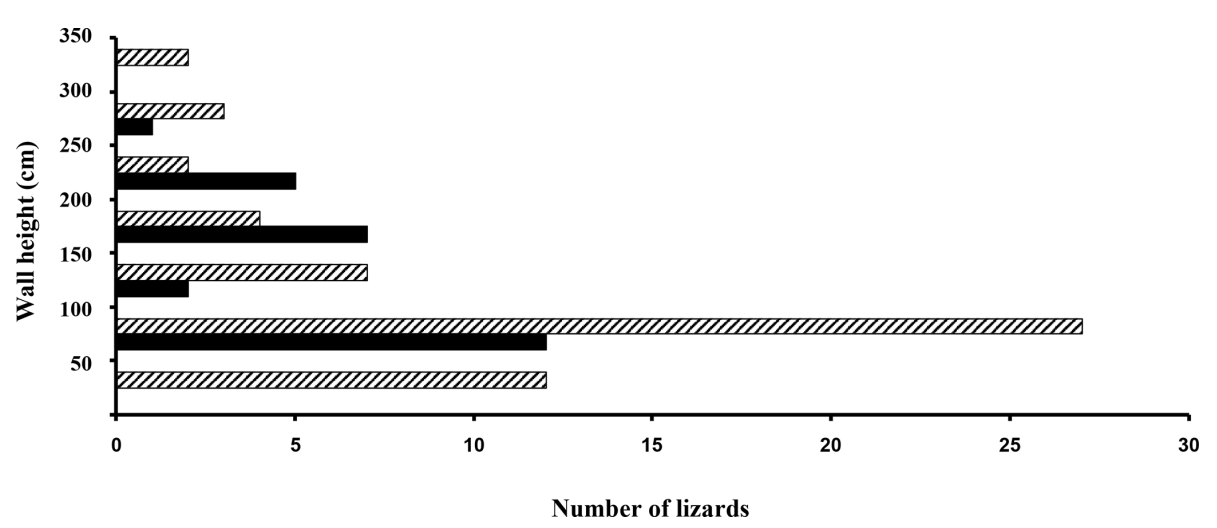

Figure 5. Histograms of lizard heights on the wall next to heat panels (black bars) and those lizards located on unheated wall areas (crosshatched).
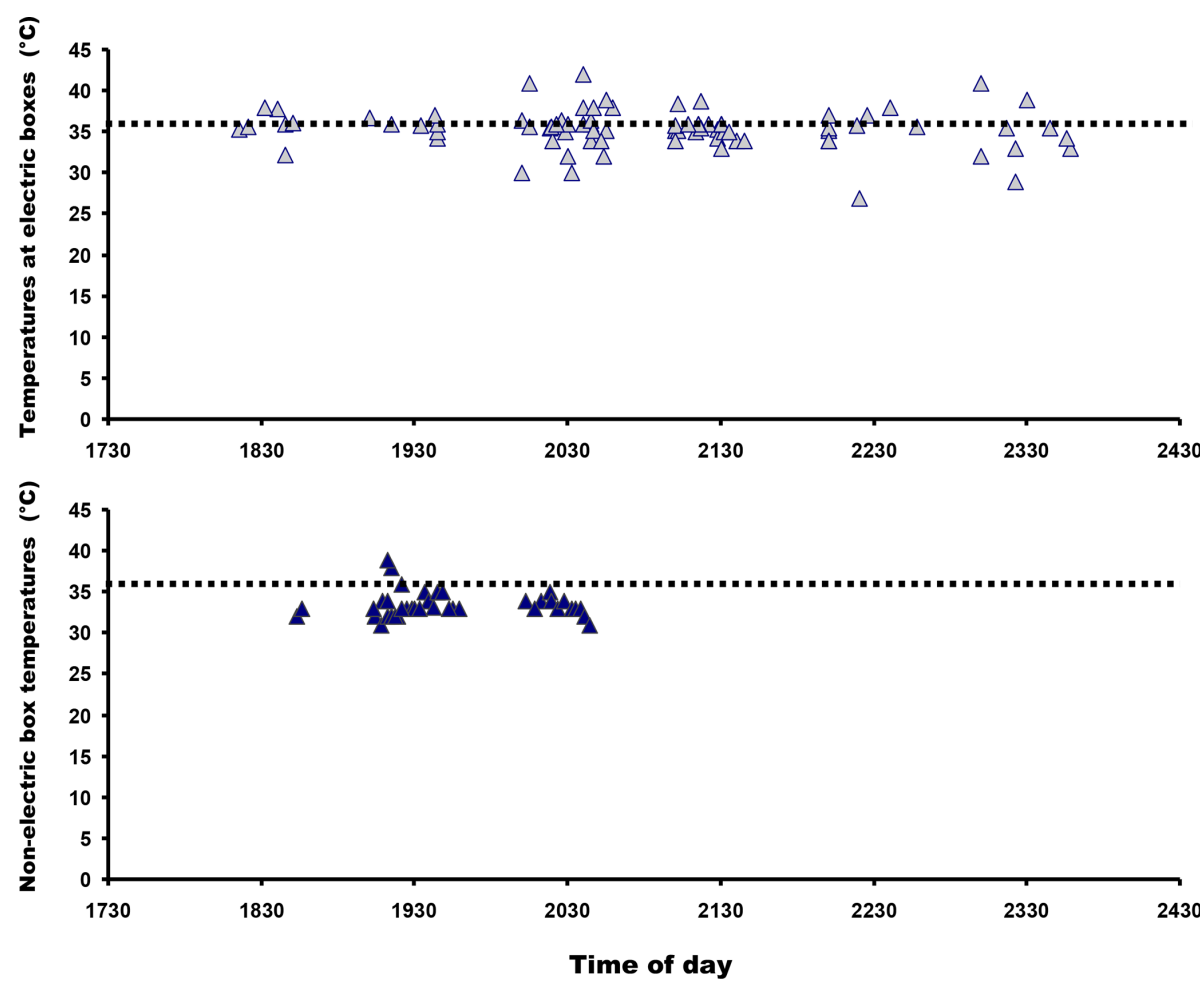

Figure 6. Lizard locations in relation to heated panels (top graph) and areas without heat panels in relation to minimum preferred body temperatures known in this species shown as dotted lines. The graphs suggest that lizards associated with heated panels were more likely to have body temperatures within the minimum PBT than those lizards that were not.

els are a limiting resource. This latter hypothesis is unlikely, given that around $65 \%$ of the electric panels were not used by A. agama but were used by geckos (Hemidactylus angulatus), which may possibly be a nocturnal competitor with $A$. agama. Snakes of the genus Lamprophis and cats are mainly nocturnal foraging predators (for snakes see Akani et al., 2008; Chippaux and Jackson, 2019; for cats see Ogan and Jurek, 1997; Hall et al., 2000). Our observations of predation events support the notion of (i) A. agama constituting an important food source for the mesopredator communi- ties inhabiting suburban Afrotropical areas (Luiselli et al., 2002; Akani et al., 2008; Rodewald and Gehrt, 2014) and that (ii) there should be high risks for diurnal terrestrial activity, especially movement between diurnal home territories and retreats sites. Electrical panel retreats are apparently so valuable that lizards will travel increased distances to access them. We assume there must be benefits gained from these movements and that the benefits outweigh the risks from exposure to predation. Otherwise, we would expect natural selection to work against this behaviour (Lima and Dill, 1990; 
Fahrig, 2007), which it clearly does not. However, we do not know when the lizards adopted this behaviour and whether there is a long-term selective advantage to retreat site selection. Nevertheless gaining heat from warm overnight retreat sites to elevate body temperatures must increase the capacity for fast movement due to $Q_{10}$ effects on body temperature (Bennett, 1990) and even reduce early-morning basking costs. Increased movements and greater variation in male movement may involve territoriality, even in respect of overnight retreat sites. For example, males of A. agama are highly territorial and males with higher body temperatures would have an advantage in territory disputes due to $Q_{10}$ effects on muscular energy. Distances travelled by males were highly variable but significantly greater than travelled by females and subadults. This likely also involves territory defence since this necessitates movement (patrols) to detect the presence of rival males and is well known in other species of lizards including agamids (e.g. Meek and Avery, 2008).

The high percentage of female lizards associated with artificial heat sources could relate to the importance of high and constant body temperatures in increasing offspring fitness and survivorship in reptiles (Shine and Harlow, 1993; Angilletta et al., 2000; Lourdais et al., 2004; Löwenborg et al., 2011; Moor et al., 2020). Laboratory research has shown that elevated levels of basking opportunity and higher night temperatures during late summer in female gecko lizards increased the proportion of births occurring before winter (Moor, et al., 2020). Attaining nocturnally high body temperatures in natural environments, especially when nocturnal temperatures are lower than diurnal temperatures, may be impossible, and hence A. agama is exploiting one of the outcomes of anthropogenic environmental change.

Overnight retreats at elevated locations, for example tree branches, are not exceptional components in the habitats of African agamids and are known to reduce predation risk (Reaney and Whiting, 2003). In central Nigeria, A. agama spend the night in trees and shrubs and on buildings contrasting with terrestrial diurnal activity (Cloudsley-Thompson, 1981). Nocturnal selection for higher perches has also been observed in other tropical lizards, including the chameleon Brookesia decaryi, normally a diurnal ground dweller, that selects higher areas such as small plants, shrubs, dead fallen branches or lianas as nocturnal retreat sites (Razafimahatratra et al., 2008).
The selection of electric panels as overnight retreat sites demonstrates a degree of behavioural flexibility in A. agama, including exploitation of the almost permanent "deficiency in public electricity supply" in Port Harcourt city and in Nigeria generally where there is widespread reliance on private generators instead of public electric power (Ado and Josiah, 2015; Nkoro et al., 2019). Despite only a small proportion of lizards being found on trees or bushes, to accurately measure this would require an estimate of how many trees and bushes were available compared to wall area availability, but for logistic reasons this was impossible to measure in the field. Also, it would be necessary to have an estimate of the likelihood to detect a lizard in a tree as opposed to a wall in order to make firm conclusions on the issue of resting site preferences. Thus, given the importance of understanding behaviour and ecology of a highly adaptable species in new and changing environments, a more experimental approach will be applied in a forthcoming phase of our research. For example, increased insight into the heat available to A. agama in its natural environment compared to urban areas will enable understanding of the comparative thermal constraints in each habitat and their impact on the lives of the lizards and how they adapt to urban areas. Such knowledge will be a first step in understanding the conservation measures required to protect A. agama should they be required at a future date. 
Appendix A

Table A1. Summary of the raw data concerning study areas (and geographic coordinates), number of Agama agama individuals observed on the electric panels, height of the electric panels, time of observation (Lagos standard time) and temperature of the electric panels (in ${ }^{\circ} \mathrm{C}$ ).

\begin{tabular}{|c|c|c|c|c|c|c|}
\hline Locality & Latitude & Longitude & $\begin{array}{l}\text { No. of lizards } \\
\text { on the panel }\end{array}$ & $\begin{array}{r}\text { Height of } \\
\text { electrical panel }\end{array}$ & Time & $\begin{array}{r}\text { Temperature } \\
\text { of panel }\end{array}$ \\
\hline Abel Jumbo Mile 3 & $40^{\circ} 47^{\prime} 6071^{\prime \prime} \mathrm{N}$ & $60^{\circ} 59^{\prime} 1242^{\prime \prime} \mathrm{E}$ & 3 & $216 \mathrm{~cm}$ & $20: 40$ & 38 \\
\hline Abuloma, Port Harcourt & $40^{\circ} 46^{\prime} 50.946^{\prime \prime} \mathrm{N}$ & $70^{\circ} 3^{\prime} 36.827^{\prime \prime} \mathrm{E}$ & 1 & $150 \mathrm{~cm}$ & 23:00 & 41 \\
\hline Agbonchia, Eleme & $40^{\circ} 47^{\prime} 46.128^{\prime \prime} \mathrm{N}$ & $70^{\circ} 7^{\prime} 10.512^{\prime \prime} \mathrm{E}$ & 3 & $195 \mathrm{~cm}$ & $21: 30$ & 36 \\
\hline Agip Estate & $40^{\circ} 48^{\prime} 34.918^{\prime \prime} \mathrm{N}$ & $60^{\circ} 59^{\prime} 02.651^{\prime \prime} \mathrm{E}$ & 2 & $152 \mathrm{~cm}$ & $20: 28$ & 35.1 \\
\hline Alode, Eleme & $40^{\circ} 46^{\prime} 40.212^{\prime \prime} \mathrm{N}$ & $70^{\circ} 07^{\prime} 18.744^{\prime \prime} \mathrm{E}$ & 2 & $80 \mathrm{~cm}$ & $21: 28$ & 35.4 \\
\hline Azikiwe Street & $40^{\circ} 47^{\prime} 40^{\prime \prime} \mathrm{N}$ & $60^{\circ} 59^{\prime} 1^{\prime \prime} \mathrm{E}$ & 4 & $86 \mathrm{~cm}$ & $21: 13$ & 34.3 \\
\hline Azikiwe Street, Diobu & $40^{\circ} 47^{\prime} 37.5^{\prime \prime} \mathrm{N}$ & $60^{\circ} 59^{\prime} 05.1^{\prime \prime} \mathrm{E}$ & 1 & $72 \mathrm{~cm}$ & $20: 30$ & 32 \\
\hline Bodo city & $40^{\circ} 78^{\prime} 100^{\prime \prime} \mathrm{N}$ & $70^{\circ} 15^{\prime} 480^{\prime \prime} \mathrm{E}$ & 1 & $120 \mathrm{~cm}$ & $21: 00$ & 35.2 \\
\hline Bomu & $40^{\circ} 39^{\prime} 37.76^{\prime \prime} \mathrm{N}$ & $70^{\circ} 17^{\prime} 0.49^{\prime \prime} \mathrm{E}$ & 1 & $86 \mathrm{~cm}$ & $18: 45$ & 36 \\
\hline Bonny Street, Port Harcourt & $40^{\circ} 45^{\prime} 32.37^{\prime \prime} \mathrm{N}$ & $70^{\circ} 1^{\prime} 34.758^{\prime \prime} \mathrm{E}$ & 3 & $95 \mathrm{~cm}$ & $20: 59$ & 38 \\
\hline Chibiari & $40^{\circ} 50^{\prime} 8^{\prime \prime} \mathrm{N}$ & $60^{\circ} 57^{\prime} 46^{\prime \prime} \mathrm{E}$ & 2 & $120 \mathrm{~cm}$ & $22: 25$ & 37 \\
\hline Eagle Island & $40^{\circ} 7929.4^{\prime \prime} \mathrm{N}$ & $60^{\circ} 9858^{\prime \prime} \mathrm{E}$ & 2 & $191 \mathrm{~cm}$ & $23: 58$ & 33 \\
\hline Eagle island & $40^{\circ} 46^{\prime} 48^{\prime \prime} \mathrm{N}$ & $60^{\circ} 58^{\prime} 53^{\prime \prime} \mathrm{E}$ & 1 & $115 \mathrm{~cm}$ & 20:00 & 30 \\
\hline Egbalor & $5.70960^{\circ} \mathrm{N}$ & $7.73080^{\circ} \mathrm{E}$ & 6 & $88 \mathrm{~cm}$ & $21: 30$ & 36 \\
\hline Egendem & $30^{\circ} 47^{\prime} 49.883^{\prime \prime} \mathrm{N}$ & $50^{\circ} 57^{\prime} 39.440^{\prime \prime} \mathrm{E}$ & 1 & $97 \mathrm{~cm}$ & $21: 13$ & 35 \\
\hline Elekahia & $40^{\circ} 49^{\prime} 11.4787^{\prime \prime} \mathrm{N}$ & $70^{\circ} 1^{\prime} 17.4292^{\prime \prime} \mathrm{E}$ & 1 & $120 \mathrm{~cm}$ & $19: 15$ & 36 \\
\hline Elelenwo & $40^{\circ} 83^{\prime} 98^{\prime \prime} \mathrm{N}$ & $70^{\circ} 07^{\prime} 27^{\prime \prime} \mathrm{E}$ & 2 & $213 \mathrm{~cm}$ & $21: 02$ & 35.2 \\
\hline Elelenwo & $40^{\circ} 49^{\prime} 20.399^{\prime \prime} \mathrm{N}$ & $70^{\circ} 4^{\prime} 28.595^{\prime \prime} \mathrm{E}$ & 1 & $74 \mathrm{~cm}$ & $20: 18$ & 35.5 \\
\hline Elelenwo & $40^{\circ} 83560^{\prime \prime} \mathrm{N}$ & $70^{\circ} 0256^{\prime \prime} \mathrm{E}$ & 2 & $70 \mathrm{~cm}$ & $18: 45$ & 32.3 \\
\hline Elelenwo & $40^{\circ} 8398^{\prime \prime} \mathrm{N}$ & $70^{\circ} 0727^{\prime \prime} \mathrm{E}$ & 2 & $213 \mathrm{~cm}$ & 21:02 & 38.5 \\
\hline Elioparanwo & $40^{\circ} 893.297^{\prime \prime} \mathrm{N}$ & $90^{\circ} 126.623^{\prime \prime} \mathrm{E}$ & 2 & $65 \mathrm{~cm}$ & 09:00 & 34 \\
\hline Elioparanwo & $40^{\circ} 49^{\prime} 52.488^{\prime \prime} \mathrm{N}$ & $60^{\circ} 57^{\prime} 18.630^{\prime \prime} \mathrm{E}$ & 1 & $200 \mathrm{~cm}$ & $22: 40$ & 38 \\
\hline Eneka & $40^{\circ} 54^{\prime} 02.747^{\prime \prime} \mathrm{N}$ & $70^{\circ} 02^{\prime} 06.749^{\prime \prime} \mathrm{E}$ & 3 & $183 \mathrm{~cm}$ & $20: 55$ & 35.2 \\
\hline Igbo-Etche & $40^{\circ} 59.1245^{\prime \prime} \mathrm{N}$ & $60^{\circ} 57.6072^{\prime \prime} \mathrm{E}$ & 1 & $150 \mathrm{~cm}$ & $18: 50$ & 36.1 \\
\hline Igwuruta & $40^{\circ} 59.7162^{\prime \prime} \mathrm{N}$ & $50^{\circ} 67.1357^{\prime \prime} \mathrm{E}$ & 1 & $81 \mathrm{~cm}$ & $20: 45$ & 34 \\
\hline Igwuruta Alimini & $40^{\circ} 58^{\prime} 4.01732^{\prime \prime} \mathrm{N}$ & $60^{\circ} 59^{\prime} 15.30895^{\prime \prime} \mathrm{E}$ & 1 & $88 \mathrm{~cm}$ & $20: 45$ & 36 \\
\hline Iloabuchi & $40^{\circ} 47^{\prime} 25.391^{\prime \prime} \mathrm{N}$ & $60^{\circ} 59^{\prime} 15.786^{\prime \prime} \mathrm{E}$ & 1 & $60 \mathrm{~cm}$ & $22: 00$ & 35.2 \\
\hline Iloabuchi & $40^{\circ} 47^{\prime} 50.843^{\prime \prime} \mathrm{N}$ & $60^{\circ} 58^{\prime} 42.827^{\prime \prime} \mathrm{E}$ & 1 & $55 \mathrm{~cm}$ & $11: 30$ & 39 \\
\hline Iloabuchi & $40^{\circ} 47^{\prime} 25.391^{\prime \prime} \mathrm{N}$ & $60^{\circ} 59^{\prime} 15.786^{\prime \prime} \mathrm{E}$ & 1 & $60 \mathrm{~cm}$ & $22: 00$ & 35.5 \\
\hline Iwofe & $40^{\circ} 47^{\prime} 50.354^{\prime \prime} \mathrm{N}$ & $60^{\circ} 58^{\prime} 42.901^{\prime \prime} \mathrm{E}$ & 1 & $125 \mathrm{~cm}$ & $20: 20$ & 34 \\
\hline Iwofe & $40^{\circ} 82782^{\prime \prime} \mathrm{N}$ & $60^{\circ} 96981^{\prime \prime} \mathrm{E}$ & 1 & $160 \mathrm{~cm}$ & $21: 15$ & 36 \\
\hline Iwofe & $40^{\circ} 48.4567^{\prime \prime} \mathrm{N}$ & $60^{\circ} 56.6776^{\prime \prime} \mathrm{E}$ & 8 & $125 \mathrm{~cm}$ & $20: 53$ & 32 \\
\hline Mgbuoba & $40^{\circ} 85^{\prime} 71^{\prime \prime} \mathrm{N}$ & $60^{\circ} 79^{\prime} 20.4^{\prime \prime} \mathrm{E}$ & 1 & $212 \mathrm{~cm}$ & $22: 58$ & 35.7 \\
\hline Mgbuoba & $40^{\circ} 51^{\prime} 49.548^{\prime \prime} \mathrm{N}$ & $60^{\circ} 58^{\prime} 14.478^{\prime \prime} \mathrm{E}$ & 2 & $180 \mathrm{~cm}$ & $20: 26$ & 36.4 \\
\hline Mgbu-Odohia & $40^{\circ} 47^{\prime} 08.598^{\prime \prime} \mathrm{N}$ & $60^{\circ} 58^{\prime} 07.824^{\prime \prime} \mathrm{E}$ & 1 & $186 \mathrm{~cm}$ & $20: 40$ & 36 \\
\hline Mile 2 Diobu & $40^{\circ} 47^{\prime} 48.026^{\prime \prime} \mathrm{N}$ & $60^{\circ} 59^{\prime} 04.966^{\prime \prime} \mathrm{E}$ & 2 & $274 \mathrm{~cm}$ & $22: 00$ & 34 \\
\hline Mile 2, Diobu & $40^{\circ} 47^{\prime} 32^{\prime \prime} \mathrm{N}$ & $60^{\circ} 59^{\prime} 28^{\prime \prime} \mathrm{E}$ & 1 & $70 \mathrm{~cm}$ & $21: 22$ & 36 \\
\hline Nkpolu & $40^{\circ} 47^{\prime} 50.994^{\prime \prime} \mathrm{N}$ & $60^{\circ} 58^{\prime} 42.66^{\prime \prime} \mathrm{E}$ & 3 & $220 \mathrm{~cm}$ & $19: 45$ & 34.3 \\
\hline Nkpolu & $40^{\circ} 87^{\prime} 48.793^{\prime \prime} \mathrm{N}$ & $80^{\circ} 55^{\prime} 88.412^{\prime \prime} \mathrm{E}$ & 2 & $89 \mathrm{~cm}$ & $20: 55$ & 39 \\
\hline Nkpolu-Rumuigbo & $40^{\circ} 47^{\prime} 50.670^{\prime \prime} \mathrm{N}$ & $60^{\circ} 58^{\prime} 43.086^{\prime \prime} \mathrm{E}$ & 2 & $74 \mathrm{~cm}$ & $20: 05$ & 41 \\
\hline Nkpolu-Oroworukwo & $40^{\circ} 47^{\prime} 49.949^{\prime \prime} \mathrm{N}$ & $60^{\circ} 58^{\prime} 43.997^{\prime \prime} \mathrm{E}$ & 1 & $126 \mathrm{~cm}$ & $19: 45$ & 35 \\
\hline Nkpolu-Oroworukwo & $40^{\circ} 80^{\prime} 6670^{\prime \prime} \mathrm{N}$ & $60^{\circ} 98^{\prime} 9947^{\prime \prime} \mathrm{E}$ & 1 & $210 \mathrm{~cm}$ & 23:00 & 32 \\
\hline Nkpolu-Rumuigbo & $40^{\circ} 52^{\prime} 41.979^{\prime \prime} \mathrm{N}$ & $60^{\circ} 58^{\prime} 50.973^{\prime \prime} \mathrm{E}$ & 1 & $183 \mathrm{~cm}$ & $19: 32$ & 35 \\
\hline Nkpor & $40^{\circ} 47^{\prime} 681^{\prime \prime} \mathrm{N}$ & $60^{\circ} 57^{\prime} 7854^{\prime \prime} \mathrm{E}$ & 1 & $172 \mathrm{~cm}$ & $21: 17$ & 35.5 \\
\hline Nwebara & $40^{\circ} 39^{\prime} 37.76^{\prime \prime} \mathrm{N}$ & $70^{\circ} 17^{\prime} 0.49^{\prime \prime} \mathrm{E}$ & 1 & $176 \mathrm{~cm}$ & $21: 30$ & 36 \\
\hline
\end{tabular}


Table A1. Continued.

\begin{tabular}{|c|c|c|c|c|c|c|}
\hline Locality & Latitude & Longitude & $\begin{array}{l}\text { No. of lizards } \\
\text { on the panel }\end{array}$ & $\begin{array}{r}\text { Height of } \\
\text { electrical panel }\end{array}$ & Time & $\begin{array}{r}\text { Temperature } \\
\text { of panel }\end{array}$ \\
\hline Ogbogoro & $40^{\circ} 51^{\prime} 5^{\prime \prime} \mathrm{N}$ & $60^{\circ} 55^{\prime} 32^{\prime \prime} \mathrm{E}$ & 1 & $64 \mathrm{~cm}$ & $19: 54$ & 36 \\
\hline Ogbunabali & $40^{\circ} 80^{\prime} 234000^{\prime \prime} \mathrm{N}$ & $70^{\circ} 01^{\prime} 14767^{\prime \prime} \mathrm{E}$ & 2 & $183 \mathrm{~cm}$ & $20: 45$ & 36.4 \\
\hline Ogoloma Okrika & $40^{\circ} 74^{\prime} 305^{\prime \prime} \mathrm{N}$ & $70^{\circ} 08^{\prime} 651^{\prime \prime} \mathrm{E}$ & 1 & $98 \mathrm{~cm}$ & $18: 15$ & 35.4 \\
\hline Ogu-Bolo & $40^{\circ} 87^{\prime} 49.684^{\prime \prime} \mathrm{N}$ & $70^{\circ} 58^{\prime} 58.423^{\prime \prime} \mathrm{E}$ & 2 & $195 \mathrm{~cm}$ & $21: 30$ & 33 \\
\hline Omkpoba, Ibaa & $40^{\circ} 48^{\prime} 03.012^{\prime \prime} \mathrm{N}$ & $60^{\circ} 57^{\prime} 48.564^{\prime \prime} \mathrm{E}$ & 2 & $244 \mathrm{~cm}$ & $22: 20$ & 27 \\
\hline Omuma Close, GRA & $40^{\circ} 485^{\prime} 065^{\prime \prime} \mathrm{N}$ & $60^{\circ} 5932^{\prime} 868^{\prime \prime} \mathrm{E}$ & 1 & $244 \mathrm{~cm}$ & $23: 22$ & 29 \\
\hline Oro-Agbolu & $40^{\circ} 48^{\prime} 32.609^{\prime \prime} \mathrm{N}$ & $60^{\circ} 59^{\prime} 00.443^{\prime \prime} \mathrm{E}$ & 3 & $183 \mathrm{~cm}$ & $20: 47$ & 38 \\
\hline Oro-Agbolu & $40^{\circ} 47^{\prime} 49.998^{\prime \prime} \mathrm{N}$ & $60^{\circ} 58^{\prime} 44.159^{\prime \prime} \mathrm{E}$ & 1 & $170 \mathrm{~cm}$ & $20: 47$ & 35.2 \\
\hline Owhonda Street & $40^{\circ} 48^{\prime} 0049^{\prime \prime} \mathrm{N}$ & $60^{\circ} 59^{\prime} 5717^{\prime \prime} \mathrm{E}$ & 1 & $135 \mathrm{~cm}$ & $23: 56$ & 34.3 \\
\hline Ozuoba & $40^{\circ} 52^{\prime} 14.891^{\prime \prime} \mathrm{N}$ & $60^{\circ} 55^{\prime} 35.160^{\prime \prime} \mathrm{E}$ & 1 & $60 \mathrm{~cm}$ & $21: 00$ & 35.8 \\
\hline Port Harcourt Town & $40^{\circ} 77^{\prime} 2186^{\prime \prime} \mathrm{N}$ & $70^{\circ} 02^{\prime} 5512^{\prime \prime} \mathrm{E}$ & 2 & $140 \mathrm{~cm}$ & $20: 52$ & 34 \\
\hline RSU Security Village & $40^{\circ} 80^{\prime} 5655^{\prime \prime} \mathrm{N}$ & $60^{\circ} 98^{\prime} 2795^{\prime \prime} \mathrm{E}$ & 1 & $120 \mathrm{~cm}$ & $6: 21$ & 35.7 \\
\hline Rukpokwu & $40^{\circ} 54^{\prime} 24.288^{\prime \prime} \mathrm{N}$ & $60^{\circ} 59^{\prime} 52.602^{\prime \prime} \mathrm{E}$ & 2 & $74 \mathrm{~cm}$ & $19: 43$ & 37 \\
\hline Rumoji & $50^{\circ} 46^{\prime} 39.539^{\prime \prime} \mathrm{N}$ & $70^{\circ} 31^{\prime} 27.417^{\prime \prime} \mathrm{E}$ & 2 & $183 \mathrm{~cm}$ & $21: 17$ & 38.7 \\
\hline Rumuaghalo & $40^{\circ} 88^{\prime} 769^{\prime \prime} \mathrm{N}$ & $60^{\circ} 99^{\prime} 141^{\prime \prime} \mathrm{E}$ & 1 & $69 \mathrm{~cm}$ & $20: 30$ & 36 \\
\hline Rumuasi & $40^{\circ} 47^{\prime} 49.637^{\prime \prime} \mathrm{N}$ & $60^{\circ} 58^{\prime} 44.735^{\prime \prime} \mathrm{E}$ & 1 & $60 \mathrm{~cm}$ & $20: 19$ & 35.7 \\
\hline Rumuchiorlu & $40^{\circ} 49^{\prime} 30.887^{\prime \prime} \mathrm{N}$ & $60^{\circ} 58^{\prime} 27.714^{\prime \prime} \mathrm{E}$ & 2 & $178 \mathrm{~cm}$ & $23: 16$ & 35.5 \\
\hline Rumuekini & $40^{\circ} 54^{\prime} 08.4^{\prime \prime} \mathrm{N}$ & $60^{\circ} 55^{\prime} 31.5^{\prime \prime} \mathrm{E}$ & 1 & $180 \mathrm{~cm}$ & $20: 40$ & 42 \\
\hline Rumueme & $40^{\circ} 82^{\prime} 41^{\prime \prime} \mathrm{N}$ & $60^{\circ} 98^{\prime} 19^{\prime \prime} \mathrm{E}$ & 1 & $220 \mathrm{~cm}$ & $19: 34$ & 35.8 \\
\hline Rumuepirikom & $40^{\circ} 47^{\prime} 41.269^{\prime \prime} \mathrm{N}$ & $60^{\circ} 58^{\prime} 56.693^{\prime \prime} \mathrm{E}$ & 2 & $216 \mathrm{~cm}$ & $18: 40$ & 37.8 \\
\hline Rumuewhara & $40^{\circ} 88^{\prime} 127^{\prime \prime} \mathrm{N}$ & $70^{\circ} 04^{\prime} 042^{\prime \prime} \mathrm{E}$ & 1 & $152 \mathrm{~cm}$ & $20: 32$ & 30 \\
\hline Rumuigbo & $40^{\circ} 47^{\prime} 803^{\prime \prime} \mathrm{N}$ & $60^{\circ} 58^{\prime} 788^{\prime \prime} \mathrm{E}$ & 1 & $64 \mathrm{~cm}$ & $18: 32$ & 38 \\
\hline Rumukalagbor & $40^{\circ} 83^{\prime} 5675^{\prime \prime} \mathrm{N}$ & $70^{\circ} 02^{\prime} 56^{\prime \prime} \mathrm{E}$ & 2 & $100 \mathrm{~cm}$ & $21: 40$ & 34 \\
\hline Rumuodara & $30^{\circ} 79^{\prime} 3121^{\prime \prime} \mathrm{N}$ & $70^{\circ} 89^{\prime} 2161^{\prime} \mathrm{E}$ & 7 & $181 \mathrm{~cm}$ & $19: 00$ & 36.7 \\
\hline Rumuodara & $50^{\circ} 0.27^{\prime} 600^{\prime \prime} \mathrm{N}$ & $70^{\circ} 9.68^{\prime} 770^{\prime \prime} \mathrm{E}$ & 1 & $187 \mathrm{~cm}$ & $21: 35$ & 35 \\
\hline Rumuodomaya & $40^{\circ} 52^{\prime} 11.898^{\prime \prime} \mathrm{N}$ & $70^{\circ} 0.03^{\prime} 731^{\prime \prime} \mathrm{E}$ & 3 & $78 \mathrm{~cm}$ & $21: 15$ & 35.9 \\
\hline Rumuokoku & $40^{\circ} 48^{\prime} 35.325^{\prime \prime} \mathrm{N}$ & $60^{\circ} 59^{\prime} 595.9625^{\prime \prime} \mathrm{E}$ & 3 & $120 \mathrm{~cm}$ & $21: 45$ & 34 \\
\hline Rumuola & $40^{\circ} 47^{\prime} 19^{\prime \prime} \mathrm{N}$ & $60^{\circ} 59^{\prime} 54^{\prime \prime} \mathrm{E}$ & 2 & $168 \mathrm{~cm}$ & $23: 22$ & 33 \\
\hline Rumuolumeni & $40^{\circ} 47.7773^{\prime \prime} \mathrm{N}$ & $60^{\circ} 57.7812^{\prime \prime} \mathrm{E}$ & 2 & $170 \mathrm{~cm}$ & 20:00 & 36.4 \\
\hline Rumuolumeni & $40^{\circ} 50^{\prime} 39.6348^{\prime \prime} \mathrm{N}$ & $70^{\circ} 0^{\prime} 14.9508^{\prime \prime} \mathrm{E}$ & 2 & $80 \mathrm{~cm}$ & $22: 00$ & 34 \\
\hline Rumuolumeni & $40^{\circ} 45.465^{\prime \prime} \mathrm{N}$ & $60^{\circ} 57.298^{\prime \prime} \mathrm{E}$ & 2 & $115 \mathrm{~cm}$ & $19: 08$ & 36 \\
\hline Rumuosi & $50^{\circ} 47^{\prime} 49^{\prime \prime} \mathrm{N}$ & $70^{\circ} 58^{\prime} 39^{\prime \prime} \mathrm{E}$ & 2 & $87 \mathrm{~cm}$ & $20: 19$ & 35.8 \\
\hline Rumuwoji & $50^{\circ} 37^{\prime} 39.582^{\prime \prime} \mathrm{N}$ & $70^{\circ} 47^{\prime} 34.312^{\prime \prime} \mathrm{E}$ & 1 & $213 \mathrm{~cm}$ & $23: 45$ & 35.5 \\
\hline Rumuwoji & $40^{\circ} 47.6071^{\prime \prime} \mathrm{N}$ & $60^{\circ} 59.1242^{\prime \prime} \mathrm{E}$ & 1 & $183 \mathrm{~cm}$ & $20: 22$ & 36 \\
\hline Rumuwoji & $40^{\circ} 46^{\prime} 50.946^{\prime \prime} \mathrm{N}$ & $70^{\circ} 3^{\prime} 36.827^{\prime \prime} \mathrm{E}$ & 1 & $72 \mathrm{~cm}$ & $20: 05$ & 35.7 \\
\hline Rumuwokerebe & $40^{\circ} 47^{\prime} 46.128^{\prime \prime} \mathrm{N}$ & $70^{\circ} 7^{\prime} 10.512^{\prime \prime} \mathrm{E}$ & 1 & $244 \mathrm{~cm}$ & $22: 00$ & 37 \\
\hline
\end{tabular}


Data availability. Data will be provided upon request from the authors.

Author contributions. NA and LL conceived the study. RM and LL carried out data analysis and wrote the manuscript including preparing figures and tables. NA, RB, HOC, DD and AC collected the data. All authors read and agreed on the final version of the manuscript.

Competing interests. The authors declare that they have no conflict of interest.

Acknowledgements. Our gratitude goes to the second-year general ecology students of the Departments of Animal and Environmental Biology, Plant Science/Biotechnology, and Microbiology (Rivers State University of Science and Technology, Port Harcourt) who were instrumental to the collection of some data while studying the habitat ecology of Agama lizards in Rivers State. We thank the two anonymous referees and the subject editor, Sonja Knapp, for helpful comments on the submitted drafts.

Review statement. This paper was edited by Sonja Knapp and reviewed by two anonymous referees.

\section{References}

Adeoye, G. O. and Ogunbanwo, O. O.: Helminth parasites of the African lizard Agama agama (Squamata: Agamidae), in Lagos, Nigeria, Rev. Biol. Trop., 55, 417-425, 2007.

Ado, A. and Josiah, M. M.: Impact of deficient electricity supply on the operations of small scale businesses in North East Nigeria, I. J. BED., 3, 1-12, 2015.

Akani, G., Ebere, N., Pérez-Mellado, V., and Luiselli, L.: Stomach flushing affects survival/emigration in wild lizards: a study case with rainbow lizards (Agama agama) in Nigeria, Amphibia-Reptilia, 32, 253-260, https://doi.org/10.1163/017353711X565493, 2011.

Akani, G. C., Luiselli, L., Eniang, E. A., and Rugiero, L.: Life in the tropical suburbs: Food type partitioning among sympatric African house snakes of the genus Lamprophis (Colubridae), Ital. J. Zool., 75, 395-399, https://doi.org/10.1080/11250000801888037, 2008.

Akani, G. C., Petrozzi, F., Rugiero, L., Segniagbeto, G. H., and Luiselli, L.: Effects of rainfall and geography on the comparative diets of eight rainbow lizard populations across Togo, Benin and Nigeria (West Africa), Amphibia-Reptilia, 34, 185192, https://doi.org/10.1163/15685381-00002881, 2013.

Akani, G. C., Luiselli, L. U. C. A., and Politano, E.: Ecological and conservation considerations on the reptile fauna of the eastern Niger Delta (Nigeria), Herpetozoa, 11, 141-153, 1999.

Amadi, N.: A Herpetofauna Survey of Rivers State (Southern Nigeria), Rivers State University Press. Port Harcourt, Rivers State Nigeria, 63 pp., 2017.
Angilletta Jr., M. J., Winters, R. S., and Dunham, A. E.: Thermal effects on the energetics of lizard embryos: implications for hatchling phenotypes, Ecology, 81, 2957-2968, https://doi.org/10.1890/00129658(2000)081[2957:TEOTEO]2.0.CO;2, 2000.

Anibaldi, C., Luiselli, L., and Angelici, F.: Notes on the ecology of a suburban population of rainbow lizards in coastal Kenya, Afr. J. Ecol., 36, 199-206, https://doi.org/10.1046/j.13652028.1998.00119.x, 1998.

Beauchamp, G.: Social predation: How Group Living Benefits Predators and Prey, Elsevier, Paris, 336 pp., 2013.

Bennett, A. F.: Thermal dependence of locomotor capacity, Am. J. Physiol., 250, 253-258, https://doi.org/10.1152/ajpregu.1990.259.2.R253, 1990.

Bonnet, X., Naulleau, G., and Shine, R.: The dangers of leaving home: dispersal and mortality in snakes, Biol. Conserv., 89, 3950, https://doi.org/10.1016/S0006-3207(98)00140-2, 1999.

Cabrera-Guzmán, E. and Reynoso, V. H.: Use of sleeping perches by the lizard Anolis uniformis (Squamata: Polychrotidae) in the fragmented tropical rainforest at Los Tuxtlas, Mexico, Rev. Mex. Biodivers., 81, 921-924, 2010.

Campbell, S. S. and Tobler, I.: Animal sleep: a review of sleep duration across phylogeny, Neurosci. Biobehav. R., 8, 269-300, 1984. https://doi.org/10.1016/0149-7634(84)90054-X

Chapman, B. M. and Chapman, R. F.: Observations on the biology of the lizard Agama agama in Ghana, Proc. Zool. Soc. Lond., 143, 121-132, 1964.

Chippaux, J.-P. and Jackson, K.: Snakes of Central and Western Africa, John Hopkins University Press, Baltimore, USA, 448 pp., 2019.

Clark, D. L. and Gillingham, J. C.: Sleep-site fidelity in two Puerto Rican lizards, Anim. Behav., 39, 1138-1148, https://doi.org/10.1016/S0003-3472(05)80786-9, 1990.

Cloudsley-Thompson, J. L.: Bionomics of the rainbow lizard Agama agama (L.) in eastern Nigeria during the dry season, J. Arid Environ., 4, 235-245, https://doi.org/10.1016/S01401963(18)31565-9, 1981.

Cooper, W. E.: Risk factors affecting escape behaviour by Puerto Rican Anolis lizards, Can. J. Zool., 84, 495-504, https://doi.org/10.1139/z06-018, 2006.

Downes, S. and Shine, R.: Heat, safety or solitude? Using habitat selection experiments to identify a lizards priorities, Anim. Behav., 55, 1387-1396, https://doi.org/10.1006/anbe.1997.0705, 1998.

Ellison, G., Wolfenden, A., Kahana, L., Kisingo, A., Jamieson, J., Jones, M., and Bettridge, C. M.: Sleeping site selection in the nocturnal northern lesser galago (Galago senegalensis) supports antipredator and thermoregulatory hypotheses, Int. J. Primatol., 40, 276-296, https://doi.org/10.1007/s10764-019-00085y, 2019.

Enge, K. M., Krysko, K. L., and Talley, B. L.: Distribution and ecology of the introduced African rainbow lizard, Agama agama africana (Sauria: Agamidae), Florida Sci., 67, 303-310, 2004.

Fahrig, L.: Non-optimal animal movement in human altered landscapes, Funct. Ecol., 21, 1003-1015, https://doi.org/10.1111/j.1365-2435.2007.01326.x, 2007.

Hall, L. S., Kasparian, M. A., Van Vuren, D., and Kelt, D. A.: Spatial organization and habitat use of feral cats (Felis catus L.) in Mediterranean California, Mammalia, 64, 19-28, https://doi.org/10.1515/mamm.2000.64.1.19, 2000. 
Harris, V. A.: The Life of the Rainbow Lizard. Hutchinson Tropical Monographs, Hutchinson and Company, London, 174 pp. 1964

Hitchcock, M. A. and McBrayer, L. D.: Thermoregulation in nocturnal ecthotherms: Seasonal and intraspecific variation in the Mediterranean Gecko (Hemidactylus turcicus), J. Herp., 40, 185195, https://doi.org/10.1670/233-04A.1, 2006.

Huey, R. B.: Temperature, physiology and the ecology of reptiles, in: Biology of the Reptilia, 12 Physiology C: Physiological Ecology, edited by: Gans, C. and Pough, F. H., Academic Press, London, 1982

James, F. C. and Porter, W. C.: Behaviour- microclimatic relationships in the African rainbow lizard, Agama agama, Copeia, 1979, 585-593, https://doi.org/10.2307/1443867, 1979.

Kearney, M.: Hot rocks and much-too-hot rocks: seasonal patterns of retreat site selection by a nocturnal ectotherm, J. Therm. Biol., 27, 205-218, https://doi.org/10.1016/S0306-4565(01)00085-7, 2002.

Krause, J., Ruxton, G. D., Ruxton, G. D., and Ruxton, I. G.: Living in Groups, Oxford University Press, Oxford, UK, 228 pp., 2002.

Landeau, L. and Terborgh, J.: Oddity and the "confusion effect" in predation, Anim. Behav., 34, 1372-1380, https://doi.org/10.1016/S0003-3472(86)80208-1, 1986.

Leache, A. D., Chong, R. A., Papenfuss, T. J, Wagner, P., Bohme, W., Schmitz, A., Rodel, M. O., LeBreton, M., Ineich, I., Chirio, L., Bauer, A., Eniang, E. A., and Din, S. B. E.: Phylogeny of the genus Agama based on mitochondrial DNA sequence data, Bonn. Zool. Beit., 56, 273-278, 2009.

Leaché, A. D., Grummer, J. A., Miller, M., Krishnan, S., Fujita, M. K., Böhme, W., Schmitz, A., Lebreton, M., Ineich, I., Chirio, L., Ofori-boateng, C., Eniang, E. A., Greenbaum, E., Rödel, M.-O., and Wagner, P.: Bayesian inference of species diffusion in the West African Agama agama species group (Reptilia, Agamidae), System. Biodivers., 15, 192-203, https://doi.org/10.1080/14772000.2016.1238018, 2017.

Lima, S. L. and Dill, L. M.: Behavioural decisions made under the risk of predation; a review and prospectus, Can. J. Zool., 68, 619640, https://doi.org/10.1080/14772000.2016.1238018, 1990.

Lourdais, O., Shine, R., Bonnet, X., Guillon, M., and Naulleau, G.: Climate affects embryonic development in a viviparous snake, Vipera aspis, Oikos, 104, 551-560, https://doi.org/10.1111/j.0030-1299.2004.12961.x, 2004.

Löwenborg, K., Shine, R., and Hagman, M.: Fitness disadvantages to disrupted embryogenesis impose selection against suboptimal nest-site choice by female grass snakes, Natrix natrix (Colubridae), J. Evol. Biol., 24, 177-183, https://doi.org/10.1111/j.14209101.2010.02153.x, 2011.

Luiselli, L. and Amori, G.: Diet, chap. 8, in: Reptile Ecology and Conservation: A Handbook of Techniques, Oxford University Press, Oxford, 97-109, https://doi.org/10.1093/acprof:oso/9780198726135.003.0008, 2016.

Luiselli, L., Angelici, F. M., and Akani, G. C.: Comparative feeding strategies and dietary plasticity of the sympatric cobras Naja melanoleuca and Naja nigricollis in three diverging Afrotropical habitats, Can. J. Zool., 80, 55-63, https://doi.org/10.1139/z01$178,2002$.

Madsen, T. and Loman, J.: On the role of colour display in the social and spatial organization of male rain- bow lizards (Agama agama), Amphibia-Reptilia, 8, 365-372, https://doi.org/10.1163/156853887X00135, 1987.

Meek, R.: Retreat site characteristics and body temperatures of Saurodactylus brosseti Bons and Pasteur, 1957 (Sauria: Sphaerodactylidae), Morocc. Bull. Soc. Herp. Fr., 128, 41-48, 2008.

Meek, R.: Repeated use of roadside tunnels of the European mole (Talpa europea) as a communal nesting area by grass snakes, $\mathrm{Na}$ trix natrix: are there thermal benefits?, Herp. Bull., 139, 16-19, 2017.

Meek, R. and Avery, R. A.: Basking in the Australian water dragon Physignathus lesueurii: why do alpha males not respond to operative temperatures in the same way as adults and sub-adults?, Amphibia-Reptilia, 29, 257-262, https://doi.org/10.1163/156853808784125009, 2008.

Moor, G., Penniket, S., and Cree, A.: Greater basking opportunity and warmer nights during late pregnancy advance modal birth season in a live-bearing gecko, lowering the risk of reduced embryonic condition, Biol. J. Linn. Soc., 130, 128-141, https://doi.org/10.1093/biolinnean/blaa017, 2020.

Morris, C. L. and Lattanzio, M. S.: Intraspecific variation in tree lizard escape behaviour in relation to habitat and temperature, Behaviour, 157, 185-204 https://doi.org/10.1163/1568539X00003586, 2020.

Nkoro, E., Ikue-John, N., Okeke, W., Amabuike, I. L., and Ajaba, J. A.: Power supply and the performances of small and medium scale enterprises (SMSEs) in Rivers State, Int. J. Business Ecosyst. Strat., 1, 55-62, 2019.

Ogan, C. V. and Jurek, R. M.: Biology and ecology of feral, freeroaming, and stray cats, in: Mesocarnivores of northern California: biology, management, and survey techniques, workshop manual, edited by: Harris, J. E. and Ogan, C. V., The Wildlife Society, Humboldt State University, 87-92, 1997.

Pauwels, O. S. G., Gramentz, D., and Toham, A. K.: Agama agama (Rock-headed Agama) nocturnal activity, Herp. Rev., 35, 164 165, 2004.

Poche Jr., A. J., Powell, R., and Henderson, R. W.: Sleep-site selection and fidelity in Grenadian Anoles, Sleep, 30, 31-39, 2005.

Porter, W. P., Mitchell, J. W., Beckman, W. A., and DeWitt, C. B.: Behavioral implications of mechanistic ecology, Thermal and behavioral modeling of desert ectotherms and their microenvironment, Oecologia, 13, 1-54, https://doi.org/10.1007/BF00379617, 1973.

Rasoloharijaona, S., Rakotosamimanana, B., Randrianambinina, B., and Zimmermann, E.: Pair-specific usage of sleeping sites and their implications for social organization in a nocturnal Malagasy primate, the Milne Edwards' sportive lemur (Lepilemur edwardsi), Am. J. Phys. Anthropol., 122, 251-258, 2003.

Razafimahatratra, B., Mori, A., and Hasegawa, M.: Sleeping site pattern and sleeping behavior of Brookesia decaryi (Chamaeleonidae) in Ampijoroa dry forest, northwestern Madagascar, Current Herp., 27, 93-99, https://doi.org/10.3105/18811019-27.2.93, 2008.

Reaney, L. T. and Whiting, M. J.: Picking a tree: habitat use by the tree agama, Acanthocercus atricollis atricollis, in South Africa, Afric. Zool., 38, 273-278, 2003.

Rial, R. V., Akaârir, M., Gamundí, A., Nicolau, C., Garau, C., Aparicio, S., and Coenen, A. M.: Evolution of wakefulness, sleep and hibernation: from reptiles to mammals, Neurosci Biobehav. R., 34, 1144-1160, 2010. 
Rodewald, A. D. and Gehrt, S. D.: Wildlife population dynamics in urban landscapes, in: Urban wildlife conservation, Springer, Boston, MA, 117-147, 2014.

Shine, R. and Harlow, P.: Maternal thermoregulation influences offspring viability in a viviparous lizard, Oecologia, 96, 122-127, 1993.

Singhal, S. and Johnson, M.: The behavioral ecology of sleep: natural sleeping site choice in three Anolis lizard species, Behaviour, 144, 1033-1052, 2007.

Schlesinger C. A. and Shine R.: Selection of diurnal retreat sites by the nocturnal gekkonid lizard Oedura lesueurii, Herpetologica, 50, 156-163, 1994.
Wagner, P., Glaw, F., Glaw, K., and Böhme, W.: Studies on African Agama IV: First record of Agama agama (Sauria: Agamidae) from Madagascar and identity of the alien population on Grande Comore Island, Herp. Notes, 2, 73-77, 2009.

Webb, J. K., Pringle, R. M., and Shine, R.: How do nocturnal snakes select diurnal retreat sites?, Copeia, 4, 919-925, 2004.

Yeboah, S.: Observations on territory of the rainbow lizard, Agama agama, Afric. J. Ecol., 20, 187-192, https://doi.org/10.1111/j.1365-2028.1982.tb00289.x, 1982.

Yorzinski, J. L. and Platt, M. L.: The difference between night and day: antipredator behavior in birds, J. Ethol., 30, 211-218, https://doi.org/10.1007/s10164-011-0318-5, 2012. 